\title{
DIFFUSION OF SCIENTIFIC SHRIMP FARMING THROUGH VARIOUS STAGES OF THE ADOPTION PERIOD
}

\author{
*Swathi Lekshmi PS, Balasubramani N and Chandrakandan K \\ Tamil Nadu Agricultural University, Coimbatore 641003, India \\ Accepted: 28 September 2011
}

\begin{abstract}
Commercial shrimp culture has become to the mainstay of the coastal economy of India. The present study was undertaken among 120 shrimp farmers from the two predominant shrimp farming districts of the country. The aim of the study was to find out the various stages of diffusion of scientific shrimp farming through various stages of the adoption from 1997-2003, as well as to study the present adoption behavior of the shrimp farmers. Using a structured interview schedule each of the respondent was interviewed to know his stage of adoption of scientific shrimp farming in each of the year ranging from 1997 to 2003. The number of respondents in each stage of adoption in each of these years was worked out and expressed as percentages. The present adoption behaviour of the shrimp farmers was studied using the adoption quotient formula. The study revealed that the symbolic adoption and use adoption was high in the years 2002 and 2003 when more of the critical technologies of health and water management were developed and transferred to the target population. Practice wise adoption of the technologies revealed that the adoption behaviour was high in harvesting, pond bottom conditioning, pond bottom sterilization, liming of pond and feed management.
\end{abstract}

Key words: Srimp Farming, Adoption

\section{INTRODUCTION}

The diffusion of technology has been a powerful source of economic change since prehistory. The adoption and diffusion of technology emerged as an important research agenda in sociology, primarily in rural sociology in the 1940's and 1960's. Rogers (1962) defined diffusion of an innovation as the spread of an innovation over time of a new idea in a social system. Dasgupta (1989) said that the diffusion period is the time taken by an innovation to be adopted by all or most of the members of the social system after its introduction. On the other hand the adoption period is the time an individual takes to pass from the awareness to the adoption stage. In India among the various aquaculture technologies commercial shrimp culture technology occupies prime importance due to the fact that the total exports contributes to $85.8 \%$ of total shrimp cultured in $2001 / 02$. (Ranjan 2002).

Shrimp culture on commercial scale was started by farmers in the early 1990's and since then it has completed a little more than a decade of development in India. Against this background the present study was undertaken with the following objectives:

*Corresponding author: swathi.lekshi263@gmail.com
To study the diffusion of scientific shrimp farming through various stages of the adoption period.

To assess the present practise wise adoption behaviour of shrimp farmers.

\section{METHODOLOGY}

The research was carried out in Nellore district of Andhra Pradesh and Nagapattinam district of Tamil Nadu. Out of the three blocks selected in Nellore district, two villages from each block were selected randomly. Employing random sampling procedure 10 Shrimp farmers from each village were selected. Thus 60 shrimp farmers from Nellore district were selected. With respect to Nagapattinam district, out of the three blocks selected in the district, two villages from each block was selected randomly. Using random sampling procedure 10 shrimp farmers from each village were selected. Thus, 60 shrimp farmers from Nagapattinam district were selected. Thus the total sample size fixed for the study was 120 . The sampling method followed was multi stage random sampling.

The 120 respondents were shrimp farmers who passed through the various stages of adoption of scientific shrimp farming from 1997 to 2003, to the final adoption stage. Using a well structured 
interview schedule each of the respondent was interviewed to know his stage of adoption of scientific shrimp farming in each of the years ranging from 1997-2003. The number of respondents in each stage of adoption in each of these years was worked out and expressed as \%. To know the present adoption behaviour of the respondents ie in the year 2003, the extent of adoption of the shrimp farmers for selected twelve shrimp farming practices starting from pond preparation till harvest was studied. The adoption behaviour was measured using the adoption quotient developed by (Balasubramaniam 1988).

Adoption quotient $=\frac{\sum_{j=1}^{M}\left\{\frac{e j}{E j} \times w j\right\}}{\sum_{j=1}^{M} W_{j}} \times 100$

$\mathrm{ej}=$ Extent of adoption of $\mathrm{jth}$ practice in terms of magnitude

$\mathrm{Sj}=$ Potentiality for adoption of $\mathrm{jth}$ practice in terms of magnitude

$\mathrm{Wj}=$ Weightage assigned to $\mathrm{jth}$ practice

$\mathrm{M}=$ No. of applicable practices

$\mathrm{S}=$ Summation

\section{i Selection of improved shrimp farming practices}

In order to select the improved shrimp farming practices, the relevant literature on shrimp farming published by the Marine products export development authority, Central Institute of Brackish Water Aquaculture and State Fisheries Department were perused. Discussions were held with aquaculture scientists, aquaculture extension personnel and shrimp farmers. The practices for which the recommendations were specific were selected. As a result, 14 improved shrimp farming practices recommended for adoption by the shrimp farmers were finally selected. The selected practices and the recommendations for adoption are given below:

\section{ii. Weigthtages assigned to the improved Shrimp farming practices}

In order to find out the weightages of the practices recommended for Shrimp farming towards their contribution to obtain higher yields a proforma with a list of 14 practices was prepared as shown in Appendix VIII, Annexure-I A. To rate each practice on a five point continuum of importance viz., most important, more important, important, less important and least important, these proforma were given to 20

\section{Selected Recommendations}

1. Pond Bot- Flushing of entire pond bed, maintaining tom Con- water level upto a depth of $10-15 \mathrm{~cm}$, and ditioning draining out of water after 1-2 days.

2. Pond Bot- Application of 1-2t/ha of hydrated or burnt tom sterili-lime/Application of $1-2 \mathrm{~g} / \mathrm{m}^{3}$ of potassium zation permanganate / Application of Benzal konium chloride at the rate of 0.5-1.0 ppm level into the pond /Application of organic iodine at 0.5-1.0 ppm concentration.

3. Measure- Small soil samples are taken from atleast ment of 10 places in hectare pond. Samples should Soil $\mathrm{pH}$ be from top $3-5 \mathrm{~cm}$ of soil. In a pond where culture has been practiced for many years, measuring of $\mathrm{pH}$ with $\mathrm{pH}$ meter, $\mathrm{pH}$ pen, $\mathrm{pH}$ paper is done.

$\begin{array}{cll}\text { 4. Liming } & \text { Soil } \mathrm{pH} & \text { Lime }\left(\mathrm{CaCO}_{3}\right) \mathrm{MT} / \mathrm{ha} \\ \text { the Pond } & 3-4 & 2.0-4.0 \\ & 4-5 & 1.0-1.5 \\ & 5-6 & 0.5-1.0 \\ & 6-7 & 0.3-0.5 \\ & 7 \text { and above } & \text { None }\end{array}$

5. Use of Tea seed cake-20mg /litre

Predator Eradication

6. Manure Organic manure-500-1000kg/ha and Ferti- Ammonium sulphate-50kg/ha lizer

Applica- Super phosphate / triple super phosphate tion $\quad 25 \mathrm{~kg} / \mathrm{ha} \quad$ after algal

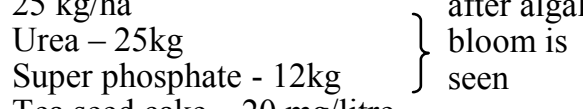
Tea seed cake $-20 \mathrm{mg} /$ litre

7.Acclimatis Shrimp seeds are first procured from govation and ernment / private hatcheries Retain 3-5 Stocking bags at random count the post larvae in of Fry each bag. No. seeds received

$=$ average count/bag $\times$ No. of bags received Time of stocking is done during early morning or after $8.00 \mathrm{pm}$ on sunny days. Float the bags on surface of pond water for 30 minutes

Open the bags

Introduce pond water into bag at the rate of $200-250 \mathrm{ml} / \mathrm{minute}$ for 10 litre of transported water, until salinity, temperature and $\mathrm{pH}$ of transported water is the same as that of pond water.

Stocking density-50,000-100,000 seeds/ha

8. Water Application of BN9 and BN10

Manage-

ment

$\begin{array}{lll}\mathrm{pH} & \begin{array}{l}\text { Dosage of } \\ \mathrm{BN} 9 \mathrm{~kg} / \mathrm{ha}\end{array} & \begin{array}{l}\text { Dosage of } \\ \mathrm{BN} \text { 10kg/ha }\end{array} \\ 6-7 & 1 & 5 \\ 5-6 & 2 & 10 \\ 4-5 & 3 & 15 \\ 3-4 & 4 & 20 \\ \text { Below 3 } & 5 & 25\end{array}$


Zeolite application

Ist week $\quad-$ no application needed

$2^{\text {nd }}$ week $\quad-$ no application needed

$3^{\text {rd }} \& 4^{\text {th }}$ Week $-25 \mathrm{~kg}$

$5^{\text {th }} \& 6^{\text {th }}$ Week $-25 \mathrm{~kg}$

$7^{\text {th }}$ to $10^{\text {th }}$ week $-50 \mathrm{~kg}$

$11^{\text {th }}$ to $15^{\text {th }}$ week $-50 \mathrm{~kg}$

9. Soil man- Soil reformer $\mathrm{kg} / \mathrm{ha}$ agement $\quad 75$

100

pH

3-4

Below 3

Drying of pond bottom between harvests have to be done. Sludge and soil waste to be subjected to treatment before disposal

\section{Feed Shrimp aged Mean \% of No. of} Manage- body wt. feed feeds

$\begin{array}{llll}\text { ment } & 12-30 & (\text { g) } & \text { age/day }\end{array}$

$\begin{array}{llll}12-30-50 & 1-3 & 10-8 & 4\end{array}$

$\begin{array}{llll}50-75 & 3-8 & 8-5.8 & 4\end{array}$

$75-90 \quad 8-15 \quad 5.8-4.5 \quad 5$

90-100 $15-20 \quad 4.5-3.7 \quad 5$

$100-110 \quad 20-25 \quad 3.7-3.3 \quad 5$

$110-120 \quad 25-30 \quad 3.3-2.9 \quad 5$

$\begin{array}{llll}120-130 & 30-33 & 2.9-2.5 & 6\end{array}$

$130-135 \quad 33-37 \quad 2.5-2.2 \quad 6$

$\begin{array}{lll}37-41 & 2.0 & 6\end{array}$

Feed broad casting distance $-2 \mathrm{~m}$ from

dike

No. of feeding trays/ha-4-6

Biomass estimation should be followed

Feed supplement - Shrimp activity $10 \mathrm{gms}$ mixed with 3 times of fresh water dried in shade for 30 minutes, mixed with feed and broadcast.

11. Health PCR tested seeds should be purchased manage- from reputed private hatcheries.

ment For controlling yellow head virus

Erythromycin-1.2 ppm, Diametin-25 ppm is recommended.

Usage of immunostimulants like immuno $\max 2.5-5 \mathrm{~g} / \mathrm{kg}$ of feed.

Probiotics usage@ Nunopro 15 3-85 -

$2.4 \mathrm{~kg} / 62 \mathrm{t}$. (water additive 86-120 days $4 \mathrm{~kg} / 62 \mathrm{t}$ )

Thionil-2kg/ha once in (soil probiotic) 15 days.

Lact-act- $10 \mathrm{~g}$ to be mixed with $1 \mathrm{~kg}$ of feed, using water and used 30 minutes after drying in shade.

12. Harvest- Total harvesting by drain capture mething od.

Avoid harvesting during new moon period.

Reduction of water depth to half in late afternoon / evening.

Admit new water into the pond

Place light above sluice/drain point

Removal of sluice screen and fix the sluice net.

judges comprising of 10 scientists from Central Institute of Brackish Water Aquaculture (CIBA) and 10 from Central Marine Fisheries Research Institute (CMFRI). The judges were requested to rate each practice in terms its de- gree of importance of adoption for getting higher yield and assign weightage on the five point continuum given against each practice. Based on the responses of the judges, the average mean score for each improved practice was worked out. The means score were tabulated and ranking was given in the descending order starting from the highest score. The practice with first to twelfth rank were selected for the study.

The ranks and the corresponding weightages attached to each practice are shown in Table 1.

Table 1. Selection of shrimp culture practices for the study

\begin{tabular}{lll}
\hline Practice & Weightage & Rank \\
\hline Health management & 4.90 & I \\
Feed management & 4.85 & II \\
Water management & 4.70 & III \\
Acclimatization and stocking & 4.55 & IV \\
Soil management & 4.55 & V \\
Liming of pond & 4.55 & VI \\
Measurement of soil pH & 4.20 & VII \\
Predator eradicator usage & 3.75 & VIII \\
Manures and fertilizer & 3.40 & IX \\
Pond bottom sterilization & 3.15 & X \\
Pond bottom conditioning & 3.1 & XI \\
Harvesting & 3.0 & XII \\
Use of pond sealing materials & 2.60 & XIII \\
Administration of antibodies & 2.00 & XIV \\
\hline
\end{tabular}

\section{iii. Determining the adoption behaviour of shrimp farmers}

The data on the extent of adoption of shrimp farming practices were collected from the respondents. The extent of adoption of each practice was compared with the recommendation and the following scoring procedure was followed to quantify the extent of adoption.

Extent of Adoption

Scores

Non-adoption of a recommended Practice 1 Partial adoption of a recommended Practice 2 Full adoption of a recommended Practice 3

\section{Diffusion of Innovations}

According to Rogers (1983) diffusion is the process by which an innovation is communicated through certain channels over time among the members of a social system. In this study, diffusion of scientific shrimp farming has been operationalised as the process by which scientific shrimp farming has been communicated through certain channels over time, among the members of a social system. The 
diffusion of shrimp farming through different stages of the adoption process such as awareness, conviction, symbolic adoption and use adoption was studied.

The diffusion of shrimp farming through different stages of the adoption process was studied by taking the scientific shrimp farming as a whole. The diffusion process was studied for a period of 7 consecutive years starting from 1997 till 2003. For this the entire sample consisting of all the 120 farmers, 60 from Nellore and 60 from Nagapattinam were considered. The method used by Halim and Islam (1975) was used for the study of diffusion of scientific shrimp farming. The distribution of the sample farmers in various stages of adoption were entered in a proforma as shown in Table 2.

\section{RESULTS AND DISCUSSION}

The diffusion of scientific shrimp farming through various stages of the adoption process for all 120 respondents; for the years ranging from 1997 to 2003 was analyzed (Table 2).

During 1997, 95.8\% of the shrimp farmers had gained awareness and conviction about shrimp farming, followed by $70.8 \%$ having symbolic adoption, and only $38.3 \%$ of the shrimp farmers had undergone use adoption (Table 2). This could be because, though shrimp culture technology, was introduced only in the early 1990 's in India, the culture gained impetus only from the mid nineties onwards, due to the development of important technologies such as technologies of feed management, manures and fertilisers and soil management. This might be the plausible reason for an overwhelming majority of the respondents having gained awareness and conviction about shrimp culture, and

Table 2:Diffusion of scientific shrimp farming through various stages of the adoption period

Sl. Year Stages of adoption and number of farmers in No. each stage

\begin{tabular}{lllllllllll} 
& & \multicolumn{3}{c}{$\begin{array}{c}\text { Awareness Convic- } \\
\text { tion }\end{array}$} & \multicolumn{3}{c}{$\begin{array}{c}\text { Symbolic } \\
\text { adoption }\end{array}$} & \multicolumn{3}{c}{$\begin{array}{c}\text { Use adop- } \\
\text { tion }\end{array}$} \\
\cline { 3 - 11 } & & No & $\%$ & No & $\%$ & No & $\%$ & No & $\%$ \\
\hline 1. & 1997 & 115 & 95.8 & 115 & 95.8 & 85 & 70.8 & 46 & 38.3 \\
2. & 1998 & 120 & 100 & 120 & 100 & 92 & 76.7 & 63 & 52.5 \\
3. & 1999 & 120 & 100 & 120 & 100 & 95 & 79.2 & 82 & 68.3 \\
4. & 2000 & 120 & 100 & 120 & 100 & 115 & 95.8 & 92 & 76.7 \\
5. & 2001 & 120 & 100 & 120 & 100 & 116 & 96.7 & 115 & 95.8 \\
6. & 2002 & 120 & 100 & 120 & 100 & 120 & 100 & 116 & 96.7 \\
7. & 2003 & 120 & 100 & 120 & 100 & 120 & 100 & 120 & 100
\end{tabular}

it is also interesting to note that a substantial \% of the farmers having undergone the symbolic adoption stage. Since the shrimp culture was in the process of gaining momentum, during this year, only $38.3 \%$ of the respondents had resorted to the adoption of scientific shrimp culture as an enterprise. It is interesting to note that during the year 1998, $100 \%$ of the respondents had gained awareness and conviction about shrimp culture, followed by $76.7 \%$ of the respondents have undergone symbolic adoption, and $52.5 \%$ have adopted shrimp culture.

During 1999, 79.2\% of shrimp farmers have undergone symbolic adoption and more than half the total respondents $(68.3 \%)$ had undergone use adoption (Table 2). This might be because the shrimp farmers might have seen for themselves the results of the adoption of improved shrimp culture technologies, by the earlier adopters, and this might have contributed substantially to their symbolic adoption and use adoption.

Further more during 2000, an overwhelming majority $(95.8 \%)$ of the respondents had undergone symbolic adoption. This might be because, it was during this year that the technologies for health management, such as Polymerase Chain Reaction (PCR) test against white spot disease were developed by the Research system; and transferred to the client system; for adoption. The development of PCR test was a major breakthrough in shrimp culture, as it was the first time, in the history of shrimp culture, that the farmers were provided with a viable technology, for screening the shrimp seeds for the presence of the white spot virus, before taking them to the culture ponds. Since the year 2000, numerous PCR testing labs operated by private companies and government, such as MPEDA, started providing PCR testing facilities for shrimp farmers. Besides it is noted that during this year, $76.7 \%$ of the farmers had adopted scientific shrimp farming.

Further, it could be observed from the Table 2 that during the year 2001, the \% of shrimp farmers who had undergone symbolic adoption and use adoption were $96.7 \%$ and $95.8 \%$ respectively. During the consecutive year of 2002 , it is observed that $100 \%$ of the respondents had undergone symbolic adoption; of which $96.7 \%$ had gone in for use adoption. 
This was followed by $100 \%$ of the respondents having adopted scientific shrimp farming as an enterprise in 2003. The diffusion of scientific shrimp culture/farming has shown encouraging results during the last 2 consecutive years of 2002 and 2003, particularly because of the development and dissemination of critical technologies of health management, (PCR test, probiotics, immuno stimulants), and water management.

The adoption behaviour of the shrimp farmers was high with respect to practices such as harvesting, pond bottom conditioning, pond bottom sterilization, acclimatization and stocking of fry, liming of pond, feed management and health management (Table 3). The average productivity for Andhra Pradesh for Penaeus monodon was $0.76 \mathrm{t} / \mathrm{ha} / \mathrm{crop}$ and that of Tamilnadu was $1.91 \mathrm{t} / \mathrm{ha}$ /crop in the year 2004 (FAO Fisheries Technical Paper, 2007). The average productivity of shrimp in Nellore district was $2 \mathrm{t} / \mathrm{ha} / \mathrm{crop}$ and that of Nagapattinam district was $2.5 \mathrm{t} / \mathrm{ha} /$ crop. The average productivity of shrimp by the farmers in the study area of both districts combined was $2.25 \mathrm{t} / \mathrm{ha} /$ crop during 2003 .

This finding is in agreement with those of $\mathrm{Ku}-$ maran et al (2003) who reported that farmers had adopted pond preparation, stocking of hatchery produced disease checked seed and application of quality pelleted feed practices, as these were a prerequisite for successful culture.

The practices such as measurement of soil $\mathrm{pH}$, manure and fertilizer application and water management had accorded comparatively low adoption behaviour. The farmers resort to measurement of soil $\mathrm{pH}$ mostly in new farms, and with respect to manure and fertilizer application,

Table 3: Adoption Behaviour of Shrimp farmers ( $\mathbf{n = 1 2 0}$ )

\begin{tabular}{lll}
$\begin{array}{l}\text { S1. } \\
\text { No }\end{array}$ Shrimp Farming Practices & $\begin{array}{l}\text { Adoption Quo } \\
\text { tient }(\%)\end{array}$ \\
\hline 1 & Pond bottom conditioning & 98.0 \\
2 & Pond bottom sterilization & 95.0 \\
3 & Measurement of Soil pH & 54.0 \\
4 & Liming the Pond & 90.0 \\
5 & Use of Predator Eradication & 87.0 \\
6 & Manure and fertilizer application & 69.0 \\
7 & Acclimatisation and stocking of fry & 92.0 \\
8 & Water management & 69.0 \\
9 & Soil management & 73.0 \\
10 & Feed management & 88.0 \\
11 & Health management & 83.0 \\
12 & Harvesting & 99.0 \\
\hline
\end{tabular}

correct usage of ammonium sulphate, urea and super phosphate were not observed. As far as water management practices were concerned, the adoption of effluent treatment plants was done only by very few farmers.

\section{CONCLUSION}

In india Commercial shrimp farming is highly attractive enterprise. Supply and demand considerations explained by expected profits from an innovation play an integral role in determining diffusion and adoption rates of innovations. The diffusion of scientific shrimp farming over a period of 7 years from 1997 to 2003 showed the mental process through which the end users of the technology pass before they adopt the technology. It was observed that production and transfer of technologies which are vital and much needed such as polymerase chain reaction tests in disease management had led to majority of the respondents into adopting scientific shrimp farming. Farmers assess a technology based on the need, economic viability and competing production practices. Hence the research system should be focused on developing more of need based technologies. The extension educators should address economic factors and feasibility criteria to enhance a farmers ability to make an informed decision.

The practice wise adoption of the shrimp farmers revealed that although the extent of adoption was relatively high for most of the practices such as measurement of soil $\mathrm{pH}$, manures and fertilizer application, water management and soil management are areas where researchers and extension personnel can focus their efforts in effective technology refinement and technology transfer.

\section{REFERENCES}

Balasubramaniam S 1988 Analysis of Technology Transfer Effectiveness in inland fish farming, Ph.D. Thesis, Tamilnadu Agricultural University, Coimbatore.

Dasgupta Satadal 1989 Diffusion of Agricultural Innovations in Village India. Wiley Eastern Limited, New Delhi.

FAO Fisheries Technical paper 4462007 Improving Penaeus monodon hatchery practices Manual based on experience in India. Aquaculture Management and conservation ervice, Fisheries and Aquaculture Management division, Rome. Pp 1. 
Kumaran M, Ponnusamy K and Kalaimani N 2003

Diffusion and Adoption of Shrimp Farming

Technologies. Aquaculture Asia April-June 2003, Vol.VIII, No.2.

Ranjan paddy 2002 Global Shrimp Outlook Fishing Chimes. Vol.22. No.9. pp.21-22.

Rogers Everett M 1962 Diffusion of Innovations, New York: The Free Press. 